\title{
Comparison of homemade and commercial yoghurt in Van province, Turkey
}

\author{
Abdulkadır TOLU ${ }^{1}$, Ibrahim ALTUN ${ }^{2 *}$ (i)
}

\begin{abstract}
Some physical, chemical, microbiological and sensory attributes of homemade and commercial yoghurts sold at 15 points of Van province in Turkey were determined. The average $\mathrm{pH}$, titration acidity, dry matter, fat-free dry matter, syneresis and protein of homemade and commercial yoghurts were 4.02 and $4.08,1.16$ and $1.10 \%, 14.55$ and $13.77 \%, 4.23$ and $3.49 \%, 10.31$ and $10.27 \%$, 29.16 and $29.32 \mathrm{ml} / 100 \mathrm{~g}, 3.61$ and 3.66\%, respectively. In homemade and commercial yoghurts, the average number of yeasts and molds was 6.02 and $3.63 \mathrm{log} \mathrm{cfu} / \mathrm{g}$; the number of L. delbrueckii subsp. bulgaricus was 7.98 and $7.78 \mathrm{log} \mathrm{cfu} / \mathrm{g}$; the number of S. thermophilus was 8.29 and $7.60 \mathrm{log} \mathrm{cfu} / \mathrm{g}$. In homemade and commercial yoghurts, the average appearance was 3.38 and 3.88, consistency was 3.01 and 3.61, odor was 3.73 and 3.89 and taste was 3.74 and 3.64.
\end{abstract}

Keywords: yoghurt; chemical parameters; physical parameters; microbiological properties.

Practical application: In this study, the physical, chemical and microbiological properties of yoghurt produced by industrial and traditional methods were compared

\section{Introduction}

Fermented dairy products with different consistency and aroma are produced especially through lactic acid fermentation with the use of various starter cultures. Among the fermented dairy products, yoghurt is the most known and consumed dairy product. Yoghurt is similar with milk in point of nutrients, but more resistant than milk (Bonczar et al., 2002). Due to significance in human nutrition, health benefits, unique taste and aroma, yoghurt consumption increase worldwide. Taste and aroma are related to production of volatile and non-volatile acids and carbonyl compounds. Homogenization and starter cultures also play a great role in taste and aroma of the yoghurts (Köse\&Ocak, 2014).

With diverse nutrients, yoghurt has several health benefits. It balances normal intestinal flora and has therapeutic effect in infantile gastroenteritis (baby diarrhea). Besides probiotic, antibiotic and antimicrobial effects, it was scientifically proved that yoghurt was effective in prevention of trace element toxifications (Kaminarides et al., 2007; Renner \&Saldaml, 1983). It was also reported that yoghurt inhibited development of some pathogenic microorganisms and reproduction of anti-tumor cells (Renner \& Saldamll, 1983). The Russian scientist, Metchnikoff, known with his scientific researches on yoghurts, indicated that the gastrointestinal disorders seen in $20^{\text {th }}$ century Europe were not seen in Turkey and Balkans. Metchnikoff indicated that since the people of these regions consume large quantities of yoghurt, they did not get intestinal disorders and lived longer. Since yoghurt contained lactic acid and the other by products, it can inhibit the development of sporulation colon bacteria able to live anaerobic ambient (Sezgin, 1981).
Different types of yoghurts are produced in different countries of the world. Along with the demands of consumers, various fruit pieces are supplemented into yoghurts to get different taste and flavors. In rural sections of Turkey, yoghurts are produced in different types such as of torba yoghurt, winter yoghurt, dry yoghurt, tulum yoghurt and Silivri yoghurt to preserved yoghurts for longer time (Ozdemir et al., 1995).

The aim of this study to determine physical, chemical, sensory and microbiological characteristics of homemade and commercial yoghurts served to markets in Van province and compliance with Fermented Dairy Products Communique of Turkish Food Codex (TFC) and TSE TS 1330 Yoghurt Standards for public health.

\section{Material and methods}

In this study, samples were taken from commercial and homemade yoghurts of 15 different points served to markets in Van province and samples were subjected to physical, chemical, sensory and microbiological analyses. Samples were preserved at $+4^{\circ} \mathrm{C}$ until the time of analysis. Chemicals used in present analyses were all at analytical purity and quality. Analyses were performed in parallels. Dry matter, fat content (Kurt et al., 2007), fat-free dry matter (Anonim, 2002), protein (AOAC, 1990), pH (Kosikowski, 1982), titratable acidity (Anonim, 1999), syneresis (Tunçtürk et al., 2000), gelatin content (Anonim, 1989), yeast-mold, yoghurt bacteria (Frank et al., 1985) and sensory analyses (Bodyfelt et al., 1988) were conducted. 
Statistical Analysis. Minimum, maximum, mean values of homemade and commercial yoghurts and standard deviations were calculated.

\section{Results and discussion}

Dry matter is the primary factor influencing yoghurt quality should be between 15.5-16.0\% (Kaminarides et al., 2007). The mean dry matter ratios of homemade and commercial yoghurts are provided in Table 1. The dry matter values of homemade yoghurts were lower than the values reported by (Eralp\&Kaptan, 1970), greater than by (Kurdal\&Demirci, 1980), close the values reported by (Senel et al., 2006). The present mean dry matter values of commercial yoghurts were lower than the values reported by (Senel et al., 2006), greater than the values reported by (Ozmen, 2012). The differences in dry matter values were mainly resulted from diversity of milks used in yoghurt production and skimming of milk fat through standard processes.

The mean fat content of homemade and commercial yoghurts is provided in Table 1. The mean fat ratios of homemade yoghurts were found to be lower than the values reported by (Sezgin, 1979), greater than the values reported by (Eralp\&Kaptan, 1970; Senel et al., 2006; Ozmen, 2012), close to values reported by (Eralp\&Kaptan, 1970). The present mean fat ratios of commercial yoghurts were lower than the values reported by (Eralp\&Kaptan, 1970), greater than the values reported by (Yildirım, 1992) and close to values reported by (Ovayurt, 2013). It was indicated in TS 1330, fat ratio should be minimum $3.8 \%$ in whole-fat yoghurts; minimum $3.0 \%$ in fatty yoghurts; minimum $1.5 \%$ in semi-skimmed yoghurts; maximum $1.5 \%$ in low-fat yoghurts; maximum $0.15 \%$ in fat-free yoghurts. $87 \%$ of homemade yoghurts were found to be whole-fat yoghurts and $13 \%$ were found to be fatty yoghurts, $47 \%$ of commercial yoghurt were whole-fat yoghurts, $40 \%$ were fatty yoghurts and 13\% were semi-skimmed yoghurts.

Table 1. Physico-chemical analysis results for homemade and commercial yoghurts.

\begin{tabular}{lcccc}
\hline Characteristics & $\mathrm{N}$ & Minimum & Maximum & \multicolumn{1}{c}{ Mean } \\
\hline Dry matter (\%) & $\mathrm{H} 15$ & 12.20 & 16.69 & $14.55 \pm 1.36$ \\
Fat (\%) & $\mathrm{H} 15$ & 3.40 & 4.95 & $4.23 \pm 0.52$ \\
Fat-free dry matter & $\mathrm{H} 15$ & 8.80 & 12.73 & $10.31 \pm 1.43$ \\
$(\%)$ & $\mathrm{H} 15$ & 3.08 & 4.86 & $3.61 \pm 0.55$ \\
Protein (\%) & $\mathrm{H} 15$ & 3.84 & 4.38 & $4.02 \pm 0.14$ \\
Ph & $\mathrm{H} 15$ & 0.93 & 1.44 & $1.16 \pm 0.16$ \\
Acidity (\%) & $\mathrm{H} 15$ & 17.60 & 37.53 & $29.16 \pm 6.09$ \\
Syneresis(ml/100g) & $\mathrm{H} 15$ & - & - & - \\
Gelatin & $\mathrm{C} 15$ & 11.10 & 15.19 & $13.77 \pm 1.12$ \\
Dry matter (\%) & $\mathrm{C} 15$ & 2.34 & 4.16 & $3.49 \pm 0.52$ \\
Fat (\%) & $\mathrm{C} 15$ & 7.08 & 11.96 & $10.27 \pm 1.17$ \\
Fat-free dry matter & $\mathrm{C} 15$ & 3.01 & 4.51 & $3.66 \pm 0.46$ \\
(\%) & $\mathrm{C} 15$ & 3.86 & 4.42 & $4.08 \pm 0.15$ \\
Protein (\%) & $\mathrm{C} 15$ & 0.91 & 1.21 & $1.10 \pm 0.11$ \\
pH & $\mathrm{C} 15$ & 15.92 & 42.03 & $29.32 \pm 7.20$ \\
Acidity (\%) & $\mathrm{C} 15$ & - & - & - \\
Syneresis(ml/100g) & & & & \\
Gelatin & & & & \\
\hline
\end{tabular}

H: Homemade, C: Commercial
The mean fat-free dry matter quantities of homemade and commercial yoghurts are provided in Table 1. Fat-free dry matter values of homemade and commercial yoghurts were similar to each other. Present values were close to values reported by (Turkoglu et al., 2003). According to Fermented Dairy Products Communique of TFC and TS 1330 Yoghurt Standard, all of the homemade yoghurts were complying with the standards and only one sample of commercial yoghurts were not complying with the standards.

According to Turkish Food Codex, protein content of yoghurts should be minimum 3.0\%. The mean protein contents of homemade and commercial yoghurts are provided in Table 1. Protein contents of homemade and commercial yoghurts were similar to each other. The present values were close to values reported by (Ozmen, 2012). Differences in protein contents were mostly because of differences in composition of milk processed into yoghurt or dry matter-dependent changes in protein contents. According to Turkish Food Codex, all of the homemade and commercial yoghurts were complying with the standards.

The mean $\mathrm{pH}$ values of homemade and commercial yoghurts are provided in Table 1. The $\mathrm{pH}$ values of homemade and commercial yoghurts were similar to each other. Present values were close to values reported by (Yildırım, 1992).

The mean titration acidity values (in terms of lactic acid) of homemade and commercial yoghurts are provided in Table 1. The mean lactic acid values of homemade and commercial yoghurts were similar to each other. Present values were close to values reported by (Atamer\&Sezgin, 1987). According to TS 1330 Yoghurt Standard, titratable acidity should be between 0.6-1.6\%. Titration acidity of homemade and commercial yoghurts was within the specified ranges of TS-1330 and TFC and such a case indicated that yoghurts were fresh.

The mean syneresis values of homemade and commercial yoghurts are provided in Table 1. The syneresis values of homemade and commercial yoghurts were similar to each other. The present values were close to values reported by (Atamer\&Sezgin, 1987). The differences in syneresis of yoghurt samples were resulted from diversity of cultures and the effects of dry matters used in yoghurt production.

Although the amount of gelatin used in yoghurt production is known to be between $0.2-0.4 \%$, researchers indicated better outcomes for gelatin ratio of $0.6 \%$ (Sezgin, 1981). Gelatin and sodium caseinate supplementations significantly reduce syneresis. It was also reported that gelatin had positive impacts on sensory attributes of the yoghurts (Akcaba, 1989). In this study, gelatin was not encountered in any of the homemade and commercial yoghurts.

Number of yeasts and molds designate the microbiological quality of yoghurts. Greater number of yeasts and molds indicate that sufficient care was not taken for hygienic conditions during the production and yoghurts were not preserved at cold environments. Yeast and mold may generate undesired taste and aroma in yoghurts though high proteolytic and lipolytic activities (Azgin, 1993). The mean number of yeasts and molds of homemade and commercial yoghurts are provided in Table 2. The present number of yeasts and molds of homemade yoghurts were close to values reported by (Gursoy et al., 2001). The present 
number of yeasts and molds of commercial yoghurts were close to values reported by (Azgin, 1993). The differences in number of yeasts and molds were mainly attributed to production methods, storage conditions and contaminations. In TS 1330 Yoghurt Standards, the upper limit for yeast and mold was set as $1.0 \times 10^{2} \mathrm{cfu} / \mathrm{g}$. According to Fermented Dairy Products Communique of Turkish Food Codex, number of yeasts and molds should be maximum $1.0 \times 10^{2}$ and $1.0 \times 10^{3} \mathrm{cfu} / \mathrm{g}$. Based on these values, it was observed that all of the homemade yoghurts were not complying with TS 1330 Yoghurt Standards and Fermented Dairy Products Communique of Turkish Food Codex. On the other hand, only $20 \%$ commercial yoghurts were complying with TS 1330 Yoghurt Standards and 26.6\% were complying with Fermented Dairy Products Communique of Turkish Food Codex.

As it was stated in Yoghurt Standard, there should not be any living microorganisms in yoghurts, except for yoghurt bacteria (S. thermophilus and L. delbrueckiisubspbulcaricus). It was reported in previous researches that only the yoghurt bacteria were required in yoghurt production and the other microorganisms spoiled taste, aroma, texture and appearance and shorten the shelf life of yoghurts (Kaminarides et al., 2007). The mean number of S.thermophilus of homemade and commercial yoghurts are provided in Table 2. The value of homemade and commercial yoghurts were close to values reported by (CaisSokolinska\&Pikul, 2004). According to fermented Dairy Products Communique of Turkish Food Codex, total number of specific microorganisms should be minimum $1.0 \times 10^{7} \mathrm{cfu} / \mathrm{g}$. The mean number of specific microorganisms was identified as 8.13 and $7.69 \log \mathrm{cfu} / \mathrm{g}$ for homemade and commercial yoghurts. Present values of homemade and commercial yoghurts were greater than the value specified in Turkish Food Codex. While number of $L$. delbrueckii subsp. bulgaricus bacteria of homemade and commercial yoghurts were similar to each other, number of S.thermophilus bacteria was different. Such differences were resulted from type and ratio of starter culture, hygienic conditions, milk microflora etc.

Appearance is a significant sensory attribute of yoghurts. A wellmanufactured yoghurt should have a bright and homogeneous appearance, syneresis should not be observed and there should not be any molds (Cais-Sokolinska\&Pikul, 2004). The mean appearance scores of homemade and commercial yoghurts are provided in Table 3. The present mean appearance scores of homemade yoghurts were similar to (Yazıc1, 1991). The mean values of commercial yoghurts were greater than the values reported by (Yazıc1, 1991). Differences in appearance scores were resulted from polluted nature of milk used in yoghurt production, possible burns during heat treatments, animal feeding and fat content of raw milk. Such differences may also be resulted from differences in type and quality of milks and yeasts and storage conditions.

Consistency is a significant quality criterion for yoghurts. A well consistency indicates homogeneous appearance free of any splits and cracks and syneresis (Yazıc1, 1991). The mean consistency scores of homemade and commercial yoghurts are provided in Table 3. The present values of homemade yoghurts were similar to values reported by (Yaz1c1, 1991). The present consistency scores of commercial yoghurts were greater than (Yazıc1, 1991). Such differences were attributed to high incubation temperatures or excessive yeast supplementations.

The mean odor scores of homemade and commercial yoghurts are provided in Table 3 . The present odor scores of homemade yoghurts were similar to values reported by (Yazıc1, 1991). The odor scores of commercial yoghurts were greater than (Yaz1c1, 1991). Undesired odor of yoghurt was attributed to burns during the heat treatment and odor absorption of milk fat around. Malodorous feeds may also influence the odor of milk, then the odor of yoghurt made of this milk. Taste is the most significant factor influencing yoghurt quality. Complex biochemical reactions of microorganisms in starter culture designate the taste of yoghurt. Besides, taste of milk processed into yoghurt and milked animal species also significantly influence yoghurt taste (Yazıc1, 1991).

The mean taste scores of homemade and commercial yoghurts are provided in Table 3. Taste scores of homemade and commercial yoghurts were similar to each other. The taste scores

Table 3. Sensory analysis results for homemade and commercial yoghurts.

\begin{tabular}{lcccc}
\hline Characteristics & $\mathrm{N}$ & Minimum & Maximum & \multicolumn{1}{c}{ Mean } \\
\hline Appearance & $\mathrm{H} 15$ & 2.25 & 4.12 & $3.38 \pm 0.45$ \\
Consistency & $\mathrm{H} 15$ & 1.75 & 3.87 & $3.01 \pm 0.55$ \\
Odor & $\mathrm{H} 15$ & 3.00 & 4.12 & $3.73 \pm 0.27$ \\
Taste & $\mathrm{H} 15$ & 2.25 & 4.25 & $3.74 \pm 0.46$ \\
Total & $\mathrm{H} 15$ & 9.25 & 15.24 & $13.70 \pm 1.42$ \\
Appearance & $\mathrm{C} 15$ & 2.62 & 4.37 & $3.88 \pm 0.47$ \\
Consistency & $\mathrm{C} 15$ & 3.00 & 4.12 & $3.61 \pm 0.34$ \\
Odor & $\mathrm{C} 15$ & 2.87 & 4.50 & $3.89 \pm 0.41$ \\
Taste & $\mathrm{C} 15$ & 2.25 & 4.12 & $3.64 \pm 0.52$ \\
Total & $\mathrm{C} 15$ & 10.74 & 16.99 & $15.07 \pm 1.55$ \\
\hline
\end{tabular}

H: Homemade, C: Commercial

Table 2. Microbiological analysis results for homemade and commercial yoghurts.

\begin{tabular}{lcccc}
\hline Characteristics & $\mathrm{N}$ & Minimum & Maximum & Mean \\
\hline Yeast and mold (log cfu/g) & $\mathrm{H} 15$ & 4.38 & 6.70 & $6.02 \pm 0.71$ \\
Lb. delbrueckiisubs. bulgaricus (log cfu/g) & $\mathrm{H} 15$ & 7.00 & 8.74 & $7.98 \pm 0.6$ \\
Str. Thermophiles (log cfu/g & $\mathrm{H} 15$ & 7.47 & 9.36 & $8.29 \pm 0.55$ \\
Yeast and mold (log cfu/g & $\mathrm{C} 15$ & $<2$ & 6.34 & $3.63 \pm 2.09$ \\
Lb. delbrueckiisubs. bulgaricus (log cfu/g) & $\mathrm{C} 15$ & 6.64 & 8.91 & $7.78 \pm 0.6$ \\
Str.thermophilus $(\log$ cfu/g) & $\mathrm{C} 15$ & 6.63 & 8.34 & $7.60 \pm 0.48$ \\
\hline
\end{tabular}

H: Homemade, C: Fabricated 
were similar to values reported by (Ovayurt, 2013). Taste-related undesired sides of yoghurts including sour, moldy, cheesy and burning smell tastes resulted from storage conditions.

The mean total sensory scores of homemade and commercial yoghurts are provided in Table 3 . Among 15 homemade yoghurt samples, $13 \%$ were complying with the standards with respect to appearance, $40 \%$ with respect to taste and $20 \%$ with respect to odor, but homemade yoghurt samples were not complying with the standards with respect to consistency and total sensory scores. Among 15 commercial yoghurt samples, $73 \%$ were complying with the standards with respect to appearance, $40 \%$ with respect to consistency, $60 \%$ with respect to odor, $53 \%$ with respect to taste and $26.6 \%$ with respect to total score.

\section{Conclusion}

Present findings revealed that homemade and commercial yoghurts had similar physical and chemical characteristics. Microbial quality was not sufficient in both groups. While only $20 \%$ of commercial yoghurts were complying with the standards with respect to number of yeasts and molds, none of homemade yoghurts were able to comply with the standards with respect to yeast and mold quantity. With respect to sensory attributes, except for taste parameter, panelists more appreciated appearance, consistency and odor of commercial yoghurts than the homemade ones. It is recommended based on present findings that quality raw material deficiencies should be eliminated, quality and pure yeasts should be used, modern production techniques should be applied, appropriate cold-chain should be maintained and products should be served to markets through proper packaging and marketing systems.

\section{Acknowledgements}

This work was supported by Van YüzüncüYıl University, Scientific Research Projects Directorate as project number FYL-2018-6680. This study was produced from the master's thesis.

\section{References}

Akcaba, M. (1989). The effect of gelatin and sodium caseniate on yoghurt quality (Master's Thesis). Hacettepe University, Ankara.

Anonim. (1989). T.S. 1330.TSE Yayınları. Ankara.

Anonim. (1999). TS 1330, Yoğurtstandard, TürkStandartlarıEnstitüsü. Ankara.

Anonim. (2002). TS 1018, Çiğineksütü, Türkstandartlarıenstitüsü. Ankara.

Association of Official Analytical Chemists - AOAC. (1990). Official methods of analysis (15th ed.). Washington, DC: Association of Official Analysis Chemists.

Atamer, M., \&Sezgin, E. (1987). The effect of incubation acidity on quality of yoghurt. Gida, 12, 213-220.

Azgin, A. (1993). Some quality properties of commercial yoghurts in Sivas province (Master's. Thesis). Gaziosmanpasa University, Tokat.

Bodyfelt, F. W., Tobias, J., \&Trout, G. M. (1988). The sensory evaluation of dairy products. New York: Van no strand Reinhold.
Bonczar, G., Wszoleka, M., \&Siuta, A. (2002). The effects of certain factors on the properties of yoghurt made fuysalrom ewe's milk. Food Chemistry, 79(1), 85-91. http://dx.doi.org/10.1016/S03088146(02)00182-6.

Cais-Sokolinska, D., \&Pikul, J. (2004). Proportion of the microflora of lactobacillus and streptococcus genera in yoghurts of different degrees of condensation. Bulletin of the Veterinary Institute in Pulawy, 48, 443-447.

Eralp, M., \&Kaptan, N. (1970). Investigation on milk sector in Antalya. Ankara: Ankara University Agriculture Faculty.

Frank, J. F., Hankin, L., Koburger, J. A., \&Marth, E. H. (1985). Tests for group of microorganisms. In G.H.Richardson. Standart methods for examination of dairy products (15th ed., pp. 189-201). Washington: APHA.

Gursoy, O., Con, A. H., \&Gokce, R. (2001). A study on microbiological characteristics of yoghurts produced in winter in Denizli. Journal Engineering Science, 1, 81-86.

Kaminarides, S., Stamou, P., \&Massouras, T. (2007). Comparison of the characteristics of set type yoghurt made from ovine milk of different fat content. International Journal of Food Science \& Technology, 42(9), 1019-1028. http://dx.doi.org/10.1111/j.1365-2621.2006.01320.x.

Köse, S., \&Ocak, E. (2014). The taste components of yogurt and factors affects taste. Academic Food Journal, 12, 101-107.

Kosikowski, F. V. (1982). Cheese and fermented milk foods. New York: F.V. Kosikowski and Associates.

Kurdal, E., \&Demirci, M. (1980). A study on composition of yoghurts consumed in Erzurum. Atatürk University Journal Agriculture, 11, 77-84.

Kurt, A., Çamakçı, S., \&Çağlar, A. (2007). Sütvemamüllerimuayeneve analizmetodlarirehberi. Erzurum: Atatürk Üniversitesi.

Ovayurt, B. Z. (2013). A study on dry matter profile of commercial yoghurts sold in Ankara. Ankara: Ankara University.

Ozdemir, S., Gökalp, H. Y., Zorba, Ö. (1995). Storage techniques of yogurt. National Productivity Center. 548:166-177.

Ozmen, B. (2012). Isolation and identification of yeasts traditionally produced yoghurts (Ph.D. Thesis). University, Erzurum, Ataturk.

Renner, E., \&Saldaml, I. (1983). Fermented milk products for nutrition. Gida, 8, 297-311.

Senel, E., Gursel, A., Yaman, S., \&Tamucay, B. (2006). The effect of bio culture on set type yoghurt. Gida, 31, 21-26.

Sezgin, E. (1979). Some technique and biological properties of yeast used in yoghurt production in Ankara (No. 722). Ankara: Ankara University.

Sezgin, E. (1981). Yoghurt technology. Segem Yay. (No. 103), 108-120.

Tunçtürk, Y., Zorba, Ö., \&Özrenk, E. (2000). Farklıhomojenizas yonbasıncıderecelerinin set yoğurtlarınbazıfiziksel, kimyasal, mikrobiyolojikveduyusalözelliklerineetkisi. Van YüzüncüYrlÜnive rsitesiZiraatFakültesiTarımBilimleriDergisi., 10(1), 45-52.

Turkoglu, H., Atasoy, F., \&Ozer, B. (2003). Some chemical properties of milk, yoghurts and Urfa cheese produced in Şanlıurfa. Harran University Agricultural Faculty Journal, 7, 69-76.

Yazıc1, F. (1991). Sensory, physical, chemical and microbiological properties of yoghurts sold in Samsun province (Master's Thesis). OndokuzMayis University, Samsun.

Yıldırım, Z. (1992). A study on quality criterion of yoghurts obtained high and low dry matter milks with full and partial homogenization (Master's Thesis). Ankara University, Ankara. 